\title{
UNA MIRADA HACIA EL PASADO. LA FIGURA DE ALEJANDRO MAGNO EN EL TEATRO ESPANNOL DEL SIGLO XVIII
}

\author{
A LOOK TO THE PAST. \\ THE FIGURE OF ALEXANDER THE GREAT \\ IN THE SPANISH THEATRE OF THE EIGHTEENTH \\ CENTURY
}

\author{
Federico Juan Briante Benítez \\ Universidad de Sevilla \\ fbriante@us.es \\ orcid: 0000-0002-6302-710X
}

Resumen: A lo largo del siglo xviII, los Borbones invirtieron numerosos esfuerzos en consolidar su concepción, particularmente esplendorosa, del rey y de la monarquía para dejar atrás el decrépito legado de los últimos Austrias. Con ese propósito, la nueva Casa Real Española fijaría su atención en la Antigüedad grecorromana y en uno de los máximos representantes de ésta, Alejandro Magno, prototipo regio con el que los Borbones se sentían muy identificados. En este artículo analizaremos cómo se explotaría esta identificación por medio del teatro, del que siempre se había servido el poder político como herramienta propagandística.

Palabras clave: Borbones; Alejandro Magno; poder; teatro; siglo XVIII.

Abstract: Throughout the eighteenth century, the Bourbon monarchs devoted numerous efforts to consolidating their rather exalted conception of the King and the Monarchy with the aim of putting the decrepit legacy of the last Austrias far behind them. To this end, the new Royal House of Spain focussed its attention on Greco-Roman Antiquity and on one of its supreme representatives, Alexander the Great, a regal prototype with whom the Bourbons felt fully identified. In this work we analyze the way in which this identification was exploited in the theatre, a form of artistic expression which the political powers had always used as a tool for propaganda.

Keywords: Bourbons; Alexander the Great; power; theatre; eighteenth century.

Recepción: 23 de octubre de 2019; aceptación: 23 de noviembre de 2020.

D.R. () 2022. Nueva Revista de Filología Hispánica Licencia Creative Commons Attribution-NonCommercial (CC BY-NC) 4.0 International 
Cuando Felipe V llega a España a principios del siglo XviII, se encuentra con un país sumido en un clima de profundo pesimismo a causa de las numerosas dificultades que lo asediaban; el descenso demográfico provocado por las epidemias y la carencia de condiciones de higiene óptimas; la despoblación de las áreas rurales, con el consiguiente abandono de la agricultura, base de la economía nacional; la devaluación monetaria; el estancamiento del comercio y el retraso de la industria por falta de medios técnicos, etc. ${ }^{1}$ Éstos solamente eran algunos de los tantos problemas que habían dejado los Austrias menores a su paso por el trono español. Como revulsivo contra esta situación, los Borbones proponían un modelo político-administrativo de marcado carácter centralizador, cuyo principal objetivo consistía en reforzar los poderes de la Corona sobre el conjunto del Estado y reafirmar la autoridad del monarca como garante del bienestar (y, por ende, de la felicidad) de los súbditos. Siguiendo la estela de su pariente, el megalómano Luis XIV de Francia —apodado, conviene no olvidarlo, el Rey Sol—, los Borbones españoles buscaban proyectar, tanto en público como en privado, una imagen de grandeza, fastuosidad y solvencia que consolidase el liderazgo político y cultural de la dinastía en España y en el resto de Europa. Uno de los arsenales más potentes y valiosos para la construcción de este imaginario del poder era, sin lugar a dudas, el mundo grecorromano.

Como bien explica Jorge Maier Allende (2010), Felipe V - y sus sucesores luego- emprendieron una serie de acciones - fundación de academias, como la de la Historia o la de las Bellas Artes de San Fernando²; excavaciones arqueológicas; formación de colecciones de escultura y cerámica... ${ }^{3}$ - conducentes todas ellas a revitalizar la Antigüedad grecorromana; ésta se revelaba - huelga decirlo- como una de las etapas más esplendorosas de la civilización europea, no sólo en el plano

1 Sobre estos problemas, véanse, por ejemplo, los trabajos de AnEs ÁlvaREZ (1981) y Domínguez OrTiz (1981).

${ }^{2}$ En este punto conviene rememorar las siguientes palabras de Álvarez Barrientos y Herrero Carretero en su edición del Sistema de adornos del Palacio Real de Madrid: "la creación de instituciones académicas contribuía a organizar la cultura en servicio de la monarquía y, en este interés, era de la mayor importancia controlar centros como la Real Biblioteca y la Academia de la Historia, creada en 1738" (en Martín SARmiento 2002, p. 84).

${ }^{3}$ Por ejemplo, el infante don Luis, hijo de Felipe V e Isabel de Farnesio, era un gran amante del coleccionismo de obras de arte, como ha estudiado María del Rosario Peña Lázaro (1990). 
cultural, sino también en el político, a tenor del gran número de victorias y conquistas militares que se habían cosechado durante esa época; por consiguiente, no resulta extraño que los Borbones apostaran por recuperar $-\mathrm{y}$ exhibir en sus palacios, museos, fiestas, etc.- todo ese pasado glorioso que había contado con figuras tan memorables en el ámbito bélico-político como Ulises, César, Aquiles, Hércules, Eneas, Trajano, Héctor o Alejandro Magno. Especial admiración suscitó este último en la España del siglo XviII, pues el hijo de Filipo II de Macedonia era uno de los personajes de la Antigüedad que mejor encarnaba las cualidades con las que se identificaban - y querían ser identificados- nuestros primeros Borbones ${ }^{4}$; así lo vemos, por ejemplo, en el ya citado Felipe V, monarca que hizo pintar varios cuadros sobre la vida de este héroe griego destinados al Palacio de la Granja de San Ildefonso, la residencia preferida del duque de Anjou y de su esposa Isabel de Farnesio.

Ahora bien, esta utilización de Alejandro Magno como instrumento ideológico a favor de la Corona no parece limitarse únicamente al ámbito de las artes plásticas, sino que alcanzaría también a la literatura, concretamente al teatro ${ }^{5}$. Aunque ya lo era desde mucho antes, en el siglo xviII el género dramático deviene en un soporte propagandístico de primer orden, como nos recuerda el profesor Roberto Fernández:

[el teatro era] un instrumento de divulgación que podía alcanzar a mucha más gente y de forma más efectiva de lo que pudiera conseguir la incipiente prensa o la novela, cuya audiencia culta era bastante minoritaria... En palacios o en casas particulares, en teatros o en iglesias, en recintos artesanales o en eras campesinas, el teatro era una diversión para todos y en todas partes (2012, p. 53) .

Así pues, habida cuenta del enorme favor popular del que gozaba el arte de Talía en España, los Borbones no podían desaprovechar la oportunidad que les brindaban las tablas para

${ }^{4}$ Sucedía lo mismo con los Borbones franceses, ya que Luis XIII, el ya mencionado Luis XIV y el sucesor de este último, Luis XV, también admiraban profundamente a Alejandro Magno (Gómez Espelosín 2016, pp. 188 y 335-336).

${ }_{5}^{5}$ Acerca de la utilización del personaje de Alejandro Magno en las tablas, puede verse el artículo de Melchora Romanos (2002).

${ }^{6}$ Sobre el valor educativo del teatro, así como sobre su acogida entre el pueblo español setecentista, véanse Maravall 1982 y ANDioc 1987. 
transmitir una serie de mensajes que apuntalaran en los súbditos una imagen del monarca lo más positiva posible. A esto nos dedicaremos en el presente trabajo, donde nos sumergimos en cinco obras dramáticas dieciochescas en las que interviene como personaje Alejandro Magno; en las páginas que siguen se intentará escudriñar hasta qué punto la figura del militar macedonio coadyuvó a los intereses oficiales de entonces.

\section{Alejandro Magno, Paradigma del Poder borbónico Por MEDIO DEL TEATRO}

Entre las numerosas fórmulas dramáticas que triunfaron en los escenarios españoles del siglo XVIII, ocupa un lugar preeminente la comedia heroico-militar; dicha fórmula ya recibió buena acogida en la época barroca, pero será en el Setecientos cuando realmente arraigue en los gustos del público español, lo que vino motivado, entre otros factores, por un aumento en la espectacularidad de la puesta en escena de estas obras, gracias a la utilización de medios técnicos más complejos.

A la comedia heroico-militar se adscriben las cinco obras teatrales que aquí estudiaremos, cuyos títulos son los siguientes: Hay pena mayor que celos sin llegar a ser agravios y el grande Alejandro en Asia, de José Francisco Díaz Domínguez Robles (1764); Razón, justicia y honor triunfan del mayor valor. Alejandro en Scutaro, de José Calvo de Barrionuevo (1792); Alejandro en Oxidraca, de Luciano Francisco Comella (1794); Alejandro en la Sogdiana, de Gaspar Zavala y Zamora (1795); Alejandro o el generoso vencedor de Oriente, de autor anónimo $(1800)^{8}$.

${ }^{7}$ Las fechas que aparecen entre paréntesis se corresponderían con las que figuran en los testimonios (manuscritos o impresos) que se conservan de dichas obras - más tarde, aludiremos a algunos de estos testimonios a la hora de citar. Cuando no se dispone de esta información, se toma la fecha del estreno o de la primera representación conocida de la obra en cuestión; respecto a esto último, véase la Cartelera teatral madrileña del siglo XVIII, realizada por René Andioc y Mireille Coulon (1996).

${ }^{8}$ Como es posible apreciar, las comedias elegidas se circunscriben cronológicamente a los reinados de Carlos III y Carlos IV, ya que es durante ambos reinados (fundamentalmente, en el de Carlos IV) cuando proliferan las comedias heroico-militares. Esta proliferación se debe, entre otras razones, a la progresiva generalización de los avances escenográficos en los teatros populares, que arranca en la década de los sesenta/setenta del siglo XVIII, sobre todo gracias a la acción del conde de Aranda y de los suceso- 
Las dos primeras obras pertenecen a escritores prácticamente olvidados hoy día. Empezando por José Francisco Díaz Domínguez Robles (¿-?), Aguilar Piñal (1981-2002, p. 39) y Herrera Navarro (1993, p. 150) sólo le atribuyen la citada comedia, aunque Cejador y Frauca (1917, p. 164) lo hace además autor de una zarzuela, titulada La feria de Valdemoro, y de un Epítome poético de las ventajas conseguidas por el ejercicio de S.M. al mando del infante D. Felipe desde su entrada en Saboya hasta la toma de Tortosa. De la vida de Díaz Domínguez Robles no poseemos más datos que la supuesta relación de mecenazgo que le uniría al duque de Uceda y marqués de Berlanga, aristócrata al que aquél dedica su obra dramática.

Prácticamente la misma escasez de información existe en relación con el autor de Alejandro en Scutaro ${ }^{9}$, José Calvo de Barrionuevo ( $c^{-}$? ), si bien parece tratarse de un dramaturgo mucho más prolífico que el anterior, pues a su pluma se deben varias comedias, sainetes y alguna que otra loa (Cejador y Frauca 1917, p. 245; Herrera Navarro 1993, pp. 70-71).

En los dos siguientes literatos, Luciano Francisco Comella y Gaspar Zavala y Zamora, apenas insistiremos porque son sobradamente conocidos. Ambos han pasado a los anales de la historia dramática española por las numerosas comedias heroico-militares que compusieron. Al igual que Calvo de Barrionuevo, también cultivaron el teatro breve ${ }^{10}$.

En lo que se refiere a la obra El generoso vencedor de Oriente, ésta consiste en una traducción ${ }^{11}$ al español de Alessandro nelle

res de éste (como el corregidor José Antonio de Armona y Murga). Por lo demás, sabido es que la actividad dramática que se desarrolló durante los reinados de Felipe V y Fernando VI estuvo muy volcada hacia la corte y hacia el entorno próximo al rey; por ende, abunda un repertorio dramático mucho más elitista, en el que predomina el teatro musical, dado el gusto de ambos monarcas por el mismo y el importante papel que desempeñó Carlo Broschi —más conocido como "Farinelli"— en este terreno.

${ }_{9}$ Puesto que los títulos de algunas de nuestras obras dramáticas son demasiado extensos, los abreviaremos cuando aludamos a ellos, para así hacer más ligero el discurso.

${ }^{10}$ Véanse, por ejemplo, los trabajos de Fernández Cabezón (1987 y 1989) y Leal Bonmati (2008).

${ }^{11}$ Cuando hablamos de traducción para calificar esta comedia, no nos referimos a lo que hoy se entiende por tal disciplina, sino a lo que se entendía en el siglo XviII, cuando, como sabemos, imperaba un concepto muy amplio de la traducción, de modo que aquellos que la ejercían actuaban con entera libertad —en líneas generales - respecto al texto de partida. Véase LAFARGA MADUELL 1986-87, p. 230. 
Indie (1729) de Pietro Metastasio. Se desconoce la identidad del traductor, pues éste no indica su nombre en el manuscrito de la comedia y prefiere ocultarse bajo el enigmático sintagma "el traductor del Demetrio"12; según este último dato, se postularían como posibles autores de nuestra comedia los escritores Juan de Agramont y Toledo (¿1701-1769?), Vicente Camacho (¿-?) y Benito Antonio de Céspedes (1726-1787) ${ }^{13}$. Los dramaturgos Juan Agramont y Toledo y Vicente Camacho, autores ambos de comedias y de teatro breve, habrían traducido el Demetrio más o menos en la misma época, en la década de los treinta del siglo XviII: el primero dedica su obra al rey Felipe V y la destina al Teatro de los Caños del Peral, mientras que el segundo lo hace para el Teatro de la Cruz (Herrera Navarro 1993, pp. 4-6 y 72-73). Respecto a Benito Antonio de Céspedes, no resulta nada improbable que fuera él quien compusiera la comedia antedicha, pues este jesuita conquense conocía muy bien la producción dramática de Metastasio; muestra de ello es un manuscrito, formado por tres tomos, que se conserva en la Biblioteca de Castilla-La Mancha ${ }^{14}$ y que contiene, nada más y nada menos, que treinta y cinco obras (entre ellas, el Demetrio) de Metastasio, traducidas por Céspedes ${ }^{15}$. Pero además de su enorme conocimiento de la obra metastasiana, el jesuita profesaba una gran admiración por el abate italiano, ya que - como afirma el propio Céspedes en el prólogo que antepone al manuscrito de Castilla-La Mancha- el teatro de Metastasio suponía "un continuo promover virtudes y virtudes heroicas" (t. 1, f. 2r); razones todas ellas que habrían impulsado a Céspedes a inspirarse en Alessandro nelle Indie para la confección de una comedia; es más, en el citado manuscrito de ésta (Tea 1-33-17, A), aparece encabezando el texto de la comedia una frase latina extraída de la obra ciceroniana De optimo genere oratorum, un gesto que

12 Para las citas de la comedia El generoso vencedor de Oriente, seguimos el manuscrito Tea 1-33-17, A de la Biblioteca Histórica Municipal de Madrid. Por lo que toca a la cita textual en la que nos hallamos ahora, conviene aclarar que el Demetrio es una obra de Metastasio, de 1731.

${ }^{13}$ Información disponible en la Biblioteca Histórica Municipal de Madrid, http: / / catalogos. munimadrid.es / cgi-bin/ historica?TITN=468314 [consultado el 2 de septiembre de 2019].

14 Biblioteca de Castilla-La Mancha, ms. 303 (t. 1); ms. 304 (t. 2); ms. 305 (t. 3).

${ }_{15}$ Véase, a este respecto, el artículo de Cristina Martín Puente (2013), quien considera a Céspedes como "el autor que más obras tradujo de Metastasio" (p. 189). 
sólo se explicaría en alguien entendido y amante de la cultura clásica, como Céspedes, que ejerció de maestro de Humanidades en varios colegios y seminarios españoles de la época ${ }^{16}$.

Baste lo dicho sobre la autoría de los textos, que no es el tema que aquí nos ocupa, para seguir avanzando ${ }^{17}$. Cabe señalar que las cinco obras reseñadas, en cuanto pertenecientes a la fórmula dramática de la comedia heroico-militar, beben en mayor o menor grado de la historia y tienen como principal objetivo, además de satisfacer el anhelo de espectacularidad exigido por el pueblo - aspecto en el que nos detendremos más adelante-, el de "formar la conciencia política y nacional de los ciudadanos por medio de los ejemplos de nuestros héroes" (Palacios Fernández 1996, p. 145); uno de estos héroes incuestionables era Alejandro Magno, que participa como personaje en las comedias que aquí estudiamos; en ellas se dramatizan algunas de las aventuras en las que se vio envuelto el hijo de Filipo II de Macedonia a su paso por diversos lugares del imperio persa y de la India. Junto a los acontecimientos de carácter propiamente histórico - como el matrimonio del héroe griego con Rosana (Alejandro en la Sogdiana) o la batalla con el rey Poro a las orillas del Hidaspes (El generoso vencedor de Oriente) - , también se ponen en escena otros hechos cuya historicidad resulta más dudosa - como la visita de Talestres, la reina del Amazonas, al monarca macedonio (El grande Alejandro en Asia) ${ }^{18}$.

En líneas generales, la imagen política de Alejandro Magno que se desprende de estas comedias es harto positiva; dicha imagen correspondería a la del monarca guerrero ideal, a tenor de las extraordinarias virtudes que nuestros dramaturgos atribuyen al héroe macedonio, siguiendo la vasta tradición secular existente sobre este personaje histórico. Tales virtudes coinciden con algunas - que no todas- de las que quisieron plasmarse en la serie de lienzos que encargó Felipe V para el Palacio de la Granja de San Ildefonso — como antes se dijo-, un proyecto artístico ${ }^{19}$ que estuvo dirigido por el italiano Filippo Juvarra (1676-1736) y que aspiraba a ser una alegoría de las cualida-

${ }^{16}$ Sobre esto último, véase Herrera Navarro 1993, p. 105.

17 Para más detalles sobre la producción literaria de todos los autores citados, remitimos a la Bibliografía de autores españoles del siglo XVIII, de FrANCisco Aguilar Piñal (1981-2002).

$18 \mathrm{Al}$ respecto, véase Gómez Espelosín 2016, pp. 82, 114, 126 y 237.

${ }_{19}$ Muchos de los detalles sobre este proyecto pueden verse, por ejemplo, en el trabajo de Álvarez Lopera (2002). 
des que adornaban al propio duque de Anjou y, por ende, a la nueva dinastía reinante en España (Soler Villalobos 2004, pp. 28-29). Las virtudes a las que nos referimos, y de las que hablaremos a continuación, son las siguientes, en este orden: el valor, la victoria, la clemencia, la modestia, la templanza y la liberalidad.

$$
\text { *** }
$$

Iniciaremos nuestro recorrido por la personalidad de Alejandro Magno señalando uno de sus atributos más sobresalientes: el valor extremo en el campo de batalla.

La destreza militar y el arrojo en la guerra se entendían como virtudes ineludibles en todo buen monarca, de ahí que los Borbones se hicieran representar habitualmente ataviados con la armadura en muchos de sus retratos (véase Morán Turina 1988, p. 190). En este punto cabe recordar la pintura de Carlos III por Anton Rafael Mengs (Museo del Prado) o las realizadas por Antonio Carnicero (Museo de Historia) y José Vergara Ximeno (Palacio de Cervelló) de Carlos IV. Ahora bien, según la concepción borbónica del gobernante ideal, no bastaba con trasladar una imagen del monarca como soldado valeroso, sino como el más valeroso de todos los soldados; es decir, en la guerra, como en todos los demás ámbitos concernientes al Estado, el monarca debía ser el primero en actuar con ejemplaridad ante sus súbditos. A este respecto, resulta muy ilustrativo el conjunto de tapices que ideó fray Martín Sarmiento en 1750 para el Palacio Real, en los que este monje benedictino buscaba plasmar los hitos más relevantes del reinado de Felipe $\mathrm{V}$, a sabiendas de que "el palacio de un rey había de mostrar la magnificencia de su persona y representarle ante el mundo" (en Martín Sarmiento 2002, p. 33). Una gran parte de estos tapices, que finalmente no se elaboraron, reproduciría escenas bélicas del monarca; entre ellas, llaman la atención las que nos presentan

a Felipe V frente al castillo de Montjuich "a tiro de fusil", durmiendo sobre el heno y envuelto en un capote cuando la batalla de Luzzara, comiendo sobre un tambor en el sitio de Alcora, durmiendo en un coche descubierto, rodeado de muertos y heridos, tras la batalla de Villaviciosa... (Morán Turina 1988, p. 193),

escenas de las que se infiere una idea muy clara, que ya adelantábamos arriba; esto es, que "el rey en la guerra es el primer 
soldado y el modelo de su ejército, con quien se muestra totalmente solidario, tanto a la hora de demostrar su valor como a la de sufrir privaciones" (loc. cit.).

Esta primacía y ejemplaridad regias en las lides de la guerra se reflejaban perfectamente en la figura de Alejandro Magno, como es posible comprobar en las comedias aquí estudiadas; por ejemplo, a principios del acto I de Alejandro en Oxidraca, una vez que los macedonios han logrado desembarcar en la playa, el héroe griego permite a sus hombres descansar un rato mientras que él, en cambio, se queda haciendo guardia para prevenir cualquier ataque del enemigo. Veamos el fragmento:

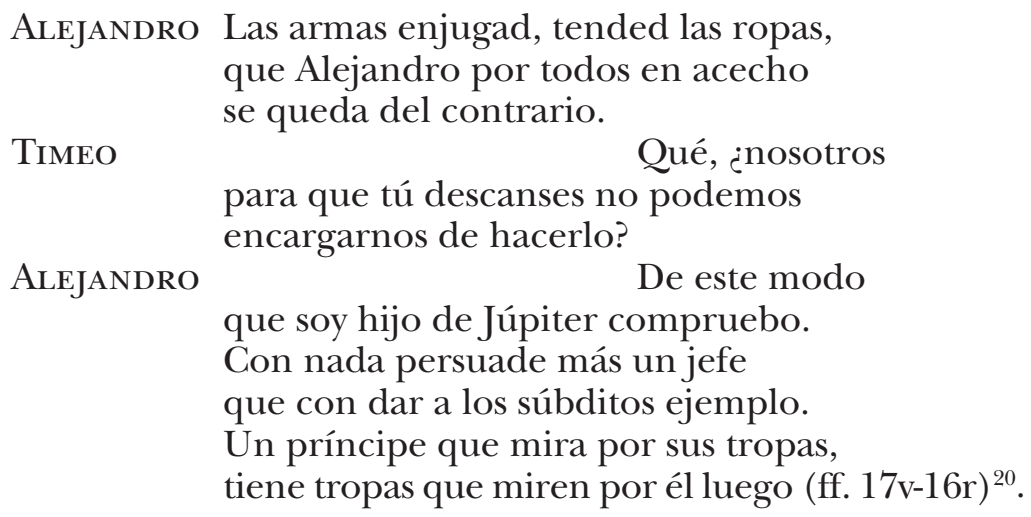

A estas declaraciones de Alejandro vienen a sumarse las que había realizado, momentos antes, durante el desembarco:
iA la orilla, invencibles campeones!
¡Mayor que la corriente es vuestro esfuerzo!
¡Ya ganamos la playa! Macedonios,
al ver que vuestro rey es el primero
que arrostra el riesgo, ¿cuál será el cobarde
que a su rey en el riesgo deje expuesto?

(f. 17r-v; cursivas añadidas).

${ }^{20}$ Citamos esta obra según el manuscrito Tea 1-1-14, B de la Biblioteca Histórica Municipal de Madrid —advertimos que dicho manuscrito tiene foliación inversa. Asimismo, también conviene señalar que, para las citas textuales de todas nuestras obras, modernizamos la ortografía y desatamos las abreviaturas — siempre que las haya-, aunque se respetan los rasgos morfosintácticos de los textos para mantener, en cierta manera, sus señas de identidad. 
Pero las ocasiones en que Alejandro luce su primacía como guerrero en esta comedia no quedan aquí; hallamos otro ejemplo en el acto III, cuando los macedonios se disponen a escalar la muralla de Oxidraca; esta empresa despertaba bastantes recelos entre los soldados, en primer lugar, por la escasez de pertrechos para efectuar el asedio con garantías, y en segundo lugar, por la llegada de un mensaje, lanzado con una flecha desde el otro lado de la muralla, donde se advertía del peligro que corría la vida de Alejandro de efectuarse dicho asedio; pese a todo ello, el hijo de Filipo II de Macedonia sigue adelante con sus planes, exhibiendo así su primogenitura militar:

\begin{tabular}{|c|c|}
\hline AlejandRo & En vano pretendéis que yo abandone \\
\hline & $\begin{array}{l}\text { el proyecto formado. Nada basta } \\
\text { a separarme de él: v si no fuera }\end{array}$ \\
\hline & $\begin{array}{l}\text { que conozco el valor que os acompaña, } \\
\text { dudara de yosotros Aunque estamos }\end{array}$ \\
\hline & tan faltos de arietes y de escalas \\
\hline & por haberse perdido mucha parte \\
\hline & $\begin{array}{l}\text { en los pasados riesgos, animadas } \\
\text { mis tropas con mi ejemplo, las alturas }\end{array}$ \\
\hline & lograron dominar de las murallas \\
\hline & y tremolar en ellas mis banderas. \\
\hline & $\begin{array}{l}\text { Cuanto más una empresa es arriesgada, } \\
\text { después de conseguida es más gloriosa; } \\
\text { todo cede al valor y a la constancia. }\end{array}$ \\
\hline Peucestes & $\begin{array}{l}\text { Es cierto, gran señor, pero el aviso } \\
\text { que te acaban de dar desde la plaza }\end{array}$ \\
\hline ALEJANDRO & Aunque en él con la muerte me amenaza \\
\hline & si penetro sus muros, no es bastante \\
\hline & a hacerme renunciar el conquistarla. \\
\hline & seré el que primero escal \\
\hline
\end{tabular}

(ff. 7r-6r; cursivas añadidas).

El mismo aspecto de Alejandro Magno se materializa en la comedia de Gaspar Zavala y Zamora aquí estudiada, Alejandro en la Sogdiana. En ella, el monarca macedonio se muestra completamente decidido a asediar la Sogdiana ese mismo día; ante el rechazo que esta idea suscita entre sus hombres, que quieren volverse a Macedonia debido - entre otras razones- a las condiciones climatológicas adversas que padecen en la zona, Alejandro les recrimina su poca resolución y les recuerda lo siguiente: 
Vosotros sois generales y sátrapas. Yo no puedo enseñar otras riquezas que las que vosotros mesmos tenéis o guardáis; de modo que solamente conservo de mis conquistas, la triste púrpura y el nombre regio. Disfruto iguales regalos que vosotros, y aún, sí, puedo mostraros mil oficiales en cuyo vestido, lecho y mesa se encuentra más regalo que el que yo tengo; pues no será porque se haya adquirido más a precio de su sangre que la mía; no, yo lo afirmo y sostengo; y si no, muestre cada uno sus heridas, que yo ofrezco mostrar las mías; y entonces, verán que no hay en mi cuerpo vena que no se haya visto rota, en distintos encuentros de espada, cuchillo, flecha o lanza enemiga, siendo cada cicatriz un mudo testigo, de que el primero soy que arrostro los peligros mandándoos con el ejemplo. Mientras vosotros dormís, yo, para guardaros, velo. Si marcháis a pie, a pie marcho; los soles, lluvias y yelos que sufrís, sufro y no más defendido de ellas y ellos que el simple soldado. He visto, como todos, el aspecto feroz a la hambre y la sed. Y en fin, cobardes, aun menos cuidado de mí he tenido, que el que de vosotros tengo (p. 8) ${ }^{21}$.

${ }^{21}$ Citamos esta obra según el ejemplar impreso Tea 1-84-1, a de la Biblioteca Histórica Municipal de Madrid. 
La maestría y valor guerreros que traslucen estos versos obedecen al espíritu victorioso, a la sed inagotable de triunfo que movía a Alejandro Magno y que, según la mentalidad borbónica, debía alentar a todo buen rey; no es casualidad, en este sentido, que la figura de la Victoria aparezca representada en los retratos que hizo Pierre Mignard de Luis XIV durante los sitios de Namur (Palacio de Versalles) y de Maastricht (Galería Sabauda), o en el de su nieto Felipe V a cargo de Jean Ranc (Museo del Prado) (Pérez Samper 2011, pp. 107-108). La victoria impulsaría al monarca a emprender grandes acciones políticas, con la mirada puesta no en la obtención de riquezas materiales, sino, ante todo, en la adquisición de fama con la que perpetuar su nombre (y el de su dinastía) en la memoria colectiva de los súbditos.

En las comedias analizadas, uno de los aspectos en el que más insiste Alejandro Magno es su ansia de ganar fama, muy por encima del deseo de gozar de muchas haciendas; así se lo hace saber el héroe macedonio a Laurante en El grande Alejandro en Asia:

No es ambición de dominios
ni de reinos la que tiene
mi valor, que sólo aspira
a que la fama resuene
por el mundo, y que se sepa
que Alejandro sólo quiere
de victorioso la gloria,
sin mirar más intereses (f. $11 \mathrm{v})^{22}$.

Igualmente, en Alejandro en Oxidraca, el hijo de Filipo II de Macedonia declara a su ejército que "de las lides no quiero los despojos / la gloria de vencer a mí me basta" (f. 17v). Semejante opinión manifiesta nuestro héroe en Alejandro en la Sogdiana; nos referimos a la escena en que Alejandro Magno renuncia a tomar parte del suculento botín adquirido en la toma del castillo de Sogdiana y lo destina íntegramente a su ejército. Su privado Hefestión, que se ha percatado de este hecho, se lo comenta a Alejandro, y éste da una respuesta que deja admirados a todos los presentes:

${ }^{22}$ Citamos esta obra según el manuscrito 15472 de la Biblioteca Nacional de España. 
HeFEstión Señor, cuanto se ha encontrado en el fuerte, repartido habéis entre todos.

\begin{tabular}{|c|c|}
\hline EJANDRO & Sí. \\
\hline HEFESTIÓN & $\begin{array}{l}\text { Ya lo veo; pero miro } \\
\text { que nada habéis reservado } \\
\text { para vos. }\end{array}$ \\
\hline ALEJANDRO & Sí tal, amigo. \\
\hline HEFESTIÓN & ¿Qué reserváis? \\
\hline ALEJANDRO & $\begin{array}{l}\text { La esperanza } \\
\text { de ver a mis pies invictos } \\
\text { todo el orbe. }\end{array}$ \\
\hline HEFESTIÓN & $\begin{array}{l}\text { ¿Quién no admira } \\
\text { vuestro proceder? }\end{array}$ \\
\hline ANAXARQUE & $\begin{array}{l}\text { Yo opino, } \\
\text { gran señor, vuestra modestia } \\
\text { perdone este arrojo mío, } \\
\text { que deben los macedonios } \\
\text { adorar, con más motivo, } \\
\text { hoy Alejandro, que a Alcides } \\
\text { ni a Baco; todos los dignos } \\
\text { hechos que a éstos granjearon } \\
\text { cultos, tan sólo debidos } \\
\text { a las deidades, no exceden } \\
\text { a los que nosotros mismos } \\
\text { en Alejandro admiramos. } \\
\text { Sus virtudes advertimos } \\
\text { que son mayores y, acaso, } \\
\text { carece de cuantos vicios } \\
\text { enormes obscurecieron } \\
\text { a aquéllos. Éste es nacido }\end{array}$ \\
\hline
\end{tabular}
(p. 16).

Una declaración de intenciones análoga hace Alejandro a Poro cuando este último recrimina al primero su afán conquistador, en la comedia El generoso vencedor de Oriente:

...Cuando a ignotos climas

llevo venciendo mi triunfante paso, arrancar no pretendo el cetro augusto a sus monarcas; no, tan sólo trato buscar ansioso una virtud que emule mi gloria y mi valor (f. 9 r) ${ }^{23}$.

${ }^{23}$ Recordamos que, para las citas de esta obra, seguimos el manuscrito Tea 1-33-17, A de la Biblioteca Histórica Municipal de Madrid. 
La imagen de Alejandro Magno que vamos tejiendo con la ayuda de estos versos consiste en la de un gobernante extremadamente valiente, de espíritu victorioso y ávido de fama, pero en absoluto avasallador o sanguinario; antes bien, su carácter corresponde al de un hombre benevolente, capaz de empatizar con sus semejantes y de sentir conmiseración (véase Gómez Espelosín 2016, p. 356). Esto último nos lleva a reparar en otra virtud regia de gran relevancia en el ideario político borbónico y, por extensión, en las monarquías occidentales: la clemencia (véase Carneiro 2013).

En las comedias objeto de nuestro estudio, Alejandro se comporta con extremada compasión hacia sus enemigos, incluso hacia aquellos que lo han tratado de manera más cruel, como es el caso de Laurante en El grande Alejandro en Asia.

Laurante, rey de Hircania, hace ostensible desde el primer momento su odio exacerbado hacia Alejandro, un sentimiento que carece de justificación ya que — como se observa nada más comenzar la comedia- el héroe griego está dispuesto a devolver a Laurante el trono de Hircania, territorio que aquél acaba de conquistar, con la única condición de que los hircanos paguen "un tributo leve" (f. 11r) a Macedonia. Este generoso ofrecimiento no impide que Laurante persista, a lo largo de toda la obra, en su obstinación hacia Alejandro Magno, lo que le impulsa a procurar la sublevación de las tropas griegas (como vemos en la carta que Laurante dirige a Talestres, ff. 34v-35r) e, incluso, a intentar asesinarlo en más de una ocasión y de modo muy cobarde (por ejemplo, al final del acto II, aprovechando que el monarca macedonio estaba dormido, f. 52v). Esta firme animadversión de Laurante hacia Alejandro, en cuanto conducta injustificada - lo que refuerza el perfil negativo del primero frente al positivo del segundo-, suscita una dura recriminación por parte de Alejandro al gobernante hircano en el siguiente fragmento de la comedia:

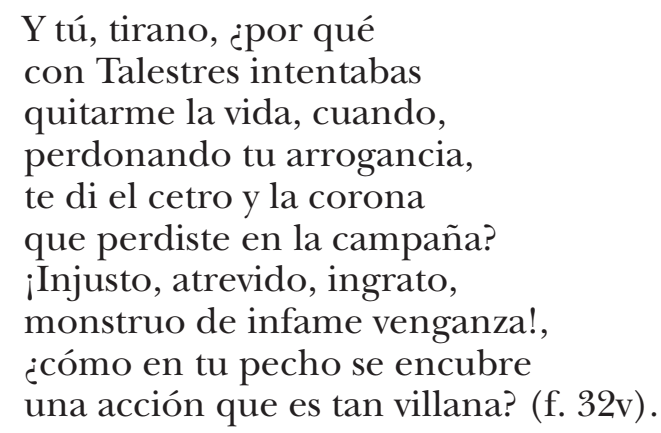


De la misma bajeza que Laurante tenemos otro personaje en la comedia de Gaspar Zavala y Zamora; se trata de Oxiarte, el gobernador del castillo de Sogdiana. Al igual que observábamos en el rey de Hircania, el trato perverso de Oxiarte hacia Alejandro no se corresponde en absoluto con el que este último le había tributado, a saber: cuando Oxiarte acude, en compañía de su futuro yerno Tribalce, ante Alejandro para recuperar a su hija Rosana, que había caído en manos de los macedonios, el héroe griego manifiesta su disposición para entregarle a la joven; dicha entrega no se produce finalmente en ese momento, no por el interés egoísta de Alejandro de retener a la muchacha, de la que se había enamorado, sino por la negativa de la propia Rosana, la cual seguía el consejo de Hefestión (p. 19). La generosidad de Alejandro llega a tal punto que, en vez de aprovechar la ocasión para capturar a Oxiarte y Tribalce, propone a este último integrarse en las filas del ejército macedonio. Pese a esta actitud afable de Alejandro, no cesa la inquina de Oxiarte contra él; tanto es así que el padre de Rosana incendia el campamento de los griegos y, además, intenta matar a Alejandro mientras éste dormía (pp. 28-29) —como Laurante en el caso anterior.

Las malas acciones cometidas por Laurante y Oxiarte en sus respectivas comedias no son óbice para que, al final, Alejandro termine concediendo el perdón a ambos hombres, a los que permite, incluso, seguir desempeñando funciones de gobierno.

Una de las comedias donde mejor se exhibe la clemencia del héroe griego es la que lleva por título El generoso vencedor de Oriente, Alejandro hace gala de esta reconocida virtud real prácticamente desde el principio de la obra: al comenzar el acto I, los macedonios, tras imponerse a los indios en el campo de batalla, procuran matar al rey Poro; en ese preciso momento sale a escena Alejandro, quien les manda detener su furia contra el vencido jefe indio y les hace la siguiente reconvención:

Tú, Jeramenes, calma los estragos, junta las tropas y refrena en ellas el ardor de matar. ¡El extremado abuso en el vencer, oh, cuánto quita mérito al vencedor! En mis soldados reine virtud que a la fortuna iguale

(f. 8r; cursivas añadidas). 
La condición clemente de Alejandro Magno reaparece en esta misma comedia hasta en dos ocasiones, en el acto III. La primera se produce cuando llega a éste la noticia de la traición que contra él había cometido Jeramenes. Aunque tenido como amigo y confidente de Alejandro, Jeramenes envidiaba en el fondo al monarca por su gran heroísmo; dicha hostilidad se recrudece, aún más, cuando Erisena, hermana de Poro y querida de Jeramenes, queda fascinada por la personalidad de Alejandro, quien había concedido la libertad a la joven tras la captura de ésta por las tropas macedonias; es entonces cuando Jeramenes, poseído por los celos, idea sublevar tales tropas a favor de Poro, de lo que nos da cuenta Gandarte a inicios del acto II: “...Cabalmente en ellos / Jeramenes el odio derramando / los hizo amigos del partido nuestro" (f. 2v). Pese a esta infame traición, Jeramenes es perdonado por Alejandro, quien no vacila en readmitir al ímprobo soldado en su ejército:
Ven a gozar mi paternal clemencia.
Ya en ese llanto renaciendo miro a mi amigo leal; ya en tu vergüenza respira la virtud. Ven a mis brazos; ven y vive feliz y en tus empresas acuérdate de mí y ama a Alejandro (f. 13r).

La segunda ocasión tiene lugar en los versos finales de la comedia, cuando el héroe griego se compadece de Poro, a quien perdona la vida, además de concederle la mano de Cleofida, renunciando así Alejandro a su amor por ésta; por si fuera poco, el hijo de Filipo II de Macedonia también agasaja a Gandarte, hombre de confianza de Poro, otorgándole el gobierno de una de sus conquistas:

Goce Poro del trono y la diadema de su imperio oriental; y por mi mano reciba amante su adorada reina; y en premio de su amor y sus virtudes, Gandarte reine en la comarca bella que allá del Ganges conquistó mi brazo. Y así, ligados en unión perpetua, para siempre vivid, mientras que ufano llevaré vuestro amor de lengua en lengua (f. 23v).

Cabe señalar que el episodio de la vida de Alejandro Magno que acabamos de describir (esto es, el perdón al rey Poro), 
fue el escogido por Filippo Juvarra para inspirar uno de los lienzos que —como antes se dijo- encargó Felipe V para el Palacio de la Granja, curiosamente el lienzo que buscaba representar la virtud de la clemencia en el monarca macedonio - y, alegóricamente, en el Borbón español- (véase Álvarez Lopera 2002, p. 142).

Junto a la clemencia, nuestros dramaturgos también atribuyen a Alejandro Magno otras virtudes que engrandecen, desde el punto de vista humano y moral, el perfil de este conocido personaje y lo consolidan como modelo del buen gobernante borbónico. Tales virtudes son la modestia, la templanza y la liberalidad.

Aunque la virtud de la modestia pudiera parecer extraña, e incluso incompatible, con el genio de un rey guerrero y ansioso de fama como Alejandro Magno, no lo es tanto dentro de los términos idílicos en los que se encuadra el retrato regio de este héroe griego (y, por extensión, de los Borbones españoles) que estamos esbozando en estas líneas. En nuestras comedias, el carácter modesto de Alejandro se materializa en su capacidad para reconocer las cualidades positivas presentes en las personas de su entorno, incluso en sus propios adversarios políticos; así lo vemos en la conversación que mantienen Poro y el monarca macedonio en el acto I de El generoso vencedor de Oriente. Poro, ocultando su identidad bajo el nombre de Asvite, da cuenta a nuestro héroe de las supuestas cualidades que caracterizan a los indios; la descripción de dichas dotes deja tan admirado a Alejandro que éste se muestra dispuesto a conceder la paz a aquel pueblo:
¡Oh, sublime valor! ¡Oh, siempre amable
fidelidad! ¡Oh, Poro afortunado con súbditos tan grandes! A tu dueño libre dirige el arrogante paso y dile que, nombrándose vencido, bien por la suerte, bien por mis soldados, deseo que por siempre brille ufana la antigua paz en su feliz estado (f. 10r).

Al término de esta comedia, Alejandro vuelve a quedar maravillado ante el comportamiento de algunos integrantes del bando de los indios, como el general Gandarte o la propia Cleofida: estos últimos ofrecen su vida a Alejandro con tal de salvar la de Poro, quien había caído en manos griegas. El hijo 
de Filipo II de Macedonia, en cuanto rey que ama y practica la virtud, valora como ejemplar el gesto solidario de ambos personajes, lo que le impulsa a liberar a Poro — como se vio más arriba一, tras exclamar lleno de admiración: "¡Conque brilla / tanta virtud sobre la indiana tierra!" (f. 23r).

Mucho más marcada se encuentra en Alejandro la virtud de la templanza, a la luz de las comedias que aquí nos ocupan. Entendida, según el DLE, como capacidad para "moderar los apetitos y el uso excesivo de los sentidos, sujetándolos a la razón", la templanza buscaba ser una de las señas de identidad de la nueva Casa Real Española, en una época en que el movimiento ilustrado preconizaba la moderación y el justo medio. Bajo esta consigna aparece simbolizada la dinastía borbónica en un grabado que realizó fray Matías de Irala partiendo de un dibujo de José Benito de Churriguera. En dicho grabado vemos a Hércules, otro de los héroes grecorromanos con el que más se identificaban los Borbones, pisando a "los monstruos de los vicios y las bajas pasiones" (Morán Turina 1988, p. 188), monstruos en los que el historiador Bonet Correa (1994, p. 32) reconoce a la Hidra y a Caco; Hércules porta, además, un caduceo en su mano derecha y, en su izquierda, una clava, que "simboliza el sometimiento de las pasiones bajo el imperio de la razón" (Morán Turina 1988, p. 188).

Como adelantábamos arriba, ese sometimiento se percibe claramente en el personaje de Alejandro Magno, tal como nos lo presentan nuestras comedias; en ellas, el héroe griego se ve sumido, en mayor o menor grado, en un conflicto entre lo que le sugieren los sentidos y lo que le dicta la razón. A dicho conflicto se llega, normalmente, por la entrada en la acción dramática de una mujer de extraordinaria belleza cuya visión encandila desde el principio a Alejandro; así ocurre con Talestres, amada de Laurante (El grande Alejandro en Asia); Timoclea, esposa de Protulo (Razón, justicia y honor triunfan del mayor valor); Demofonia, esposa de Sogramnes (Alejandro en Oxidraca); Rosana, sobrina del rey Darío y prometida de Tribalce (Alejandro en Sogdiana); y la reina Cleofida, amante de Poro (El generoso vencedor de Oriente). Como vemos, todas estas mujeres tienen el denominador común de estar vinculadas sentimentalmente con miembros del bando contrario a los macedonios, lo que agrava, más si cabe, la pugna en la que se debate Alejandro, empujado a decidir entre sus pulsiones amorosas y sus obligaciones político-militares. La comedia Alejandro en la Sogdiana nos ofrece un 
ejemplo muy ilustrativo de esta dicotomía interior: en el acto II Hefestión, junto a otros soldados, conduce a Rosana, que ha sido hecha prisionera por los macedonios, ante Alejandro; éste, al percatarse de la belleza de la joven, no se atreve siquiera a mirarla pues teme los estragos derivados de la pasión amorosa:

HEFESTIÓN

Allí está. Invicto

Alejandro, a vuestros pies

llega Rosana.

Alejandro

(Ojos míos

[Mirando a Rosana y apartando la vista de ella], cuidado que hay en los suyos muy poderoso atractivo). Aparte.

(;Oh, quieran

los dioses darme dominio para que tú no me venzas!). Aparte.

Sin mirarla la hace seña que se levante.

Rosana Muy corta anduvo la fama en los elogios que hizo de la generosidad de Alejandro, mas confío que mi labio enmendará desde hoy, señor, su descuido.

Alejandro (Alma, no la oigas [Aparte]). Esto es cumplir con vos y conmigo.

Rosana Galán es, mas ¿qué será que ni mirarme ha querido? (Pero que me mire o no, Alejandro ¿qué me importa?). Aparte.

que paséis a descansar Yo os suplico y creáis...

Rosana

Alejandro

iría sirviéndoos, si ¿Qué? no precaviera el peligro...

Rosana ¿De qué, señor? Alejandro (Pero cielos, ya no sé lo que me digo). Aparte. De que vos lo atribuyerais...

Es verdad. Vela sirviendo tú, Hefestión, en nombre mío. (Apartémosla de aquí 
cuanto antes, que si no evito

tan dulce peligro, temo

caer presto en el peligro). Aparte.

Algo muy parecido sucede en el acto I de El generoso vencedor de Oriente cuando la reina Cleofida acude, en actitud lisonjera, a Alejandro con objeto de favorecer a Poro; pese a la atracción que suscita en el héroe griego la hermosura de la reina, Alejandro contiene sus pulsiones en todo momento hasta el punto de acabar apartando su vista de Cleofida - lo mismo que hace con Rosana, recordemos. El fragmento aludido resulta demasiado extenso para reproducirlo aquí íntegramente, de modo que recogemos lo más significativo:

Alejandro (¡Qué amable rostro! ¡Qué divino encanto!). Aparte.

Cleofida (Calmemos su rigor...). Aparte.

Alejandro

(¡Alma, resiste!). Aparte.

CLEOFIDA En la augusta presencia de Alejandro me pierdo, me confundo y no sé cómo

las meditadas súplicas, en vano

llenas de confusión y abatimiento,

huyen medrosas de mi torpe labio.

Alejandro (Ingeniosas palabras...). Aparte.

CleOFidA

No pretendo

darte en rostro, oh señor, con los estragos

que llora el pueblo mío. No recuerdo

Pido tan sólo no me den tus labios

el fatal nombre de enemiga tuya; y aquesto basta a compensar mis daños.

Alejandro (¡Defiéndete, alma mía! ¡Yo me pierdo!). Aparte.

Cleofida ¿ ¿Tú no me miras y de mí apartando

huyes la vista del semblante mío?

Jamás creí me aborrecieras tanto (ff. 20v-22v).

Finalmente, este conflicto entre la pasión y la razón se resuelve a favor de la segunda fuerza, de modo que Alejandro decide renunciar a sus amadas en pro de los intereses políticomilitares a los que se debe; esto se aprecia muy bien en la comedia que acabamos de ver más arriba, El generoso vencedor de Oriente, 
en las siguientes palabras que el monarca macedonio dirige a Cleofida:

Basta, señora. Reina en tus Estados;

Se levantan. de tu calma disfruta los placeres, y si quieres triunfar con Alejandro, seré tu apoyo y protector y amigo; serélo todo en tu defensa armado. Jamás empero un corazón me pidas, que al punto de nacer fue consagrado a la gloria inmortal. Aplaudo, admiro de tu belleza el divinal encanto, mas no le adoro, no; yo soy guerrero, no soy amante en el indiano campo (f. 24r-v).

La tenacidad de Alejandro que reflejan estos versos se reafirma al final de la comedia, cuando, sabida la noticia de que la muerte de Poro había sido fingida, Alejandro renuncia completamente a la mano de Cleofida para entregársela al rey indio (f. 23v).

Esta victoria de la razón sobre los sentidos acaece igualmente en Alejandro en Oxidraca; en esta obra de Comella, el rey macedonio, llevado por su amor - que mantiene en secretoa Demofonia, realiza numerosos regalos a la joven. Ésta ansía saber las causas que motivan dichos regalos, lo que da pie a que Alejandro intente confesarle su amor; algo que finalmente no sucede, antes bien, el héroe griego opta por liberar a Demofonia para que ésta regrese con su marido, permitiéndole llevarse todos los regalos:

Demofonia Para hacer una acción digna de un héroe jamás dudó Alejandro; esto supuesto, determínate ya y dime al punto: ¿en hacerme un favor que no merezco, qué fin llevas?

Alejandro

Demofonia Digo que no le alcanzo.

Alejandro

El fin que llevo

es el de que tu amor...

Después de una pausa dice con mucha grandeza de ánimo.

Vuelva a tu esposo

y disfrutes con él del corto obsequio que a tus virtudes hace mi grandeza. ¿Quieres más de Alejandro? Dilo. 
DEMOFONIA

Quedo

tan corrida de haber de vos dudado...

Alejandro Dudaste con razón y, por lo mesmo, fuera vileza doble no vencerme cuando a vencer a tantos estoy hecho (f. 2r-v).

Sólo dos de nuestras comedias (Alejandro en Sogdiana y El grande Alejandro en Asia) acaban con un concierto matrimonial entre Alejandro y su amada correspondiente. Ahora bien, dicho concierto no supone, en ninguna de las dos obras, la rendición del héroe macedonio a los apetitos sensoriales en detrimento de los imperativos de la razón, como comprobaremos en seguida.

En Alejandro en Sogdiana, Hefestión aconseja a Alejandro deshacerse de Tribalce para que, de este modo, el monarca tuviera vía libre con Rosana; a pesar de los consejos de Hefestión, Alejandro se muestra determinado a entregar la mano de la joven a su prometido Tribalce:

Hefestión Pues tened por cierto que ella, señor, os la pagaría si apartarais a Tribalce de aquí. Rosana es altiva, es noble; la amó y con él se encuentra comprometida y no se atreve a dejarle por no exponerse a su vista y reconvenciones. Vos alejadle a toda prisa de aquí y dejad lo demás a mi cargo.

Alejandro ¿Y qué dirían de mí los que lo supieran?

Hefestión Que preferís a la misma de Tribalce vuestra propia quietud.

Alejandro Yque me valía del poder de vencedor para usurparle su dicha. ¿Cómo, Hefestión, me aconsejas? Mas yo debo, mientras viva, proceder como Alejandro. Hola.

PARMENión Señor. Alejandro A mi vista 
venga el sogdiano. Y tú, amigo, Vase Parmenión. ve a ver a Rosana y dila que la espero aquí.

HeFESTIóN Voy. (¿Qué [Aparte]

será lo que hacer maquina?). Vase.

PARMENIÓN

está el sogdiano.

Aquí

Tribalce

¿con qué linaje de muerte

Desdichas, querrá dar fin a mi vida?

Rosana Señor, temerosa llego...

Alejandro Leva[n]tad. Parmenión, quita las prisiones a Tribalce [Lo hace]

y vuélvele sus antiguas armas.

Rosana y Tribalce ¡Dioses!

PARMENIÓN

No replico. Vase.

Hefestión ¿Qué oigo? Alejandro delira.

Alejandro Si a Alejandro conocierais a fondo, no extrañaríais, Rosana, esta acción. Yo puedo más que las pasiones mías, señora, y prefiero siempre mi gloria a mi gusto.

Tribalce (Dichas,

Alejandro Y puesto que a Tribalce tenéis la mano ofrecida, se la habéis de dar mañana, que es justo y os lo suplica así Alejandro... (pp. 26-27).

Pero el proyectado enlace entre Rosana y Tribalce no se llevaría a efecto a causa de la repentina muerte de este último. Todo sucede cuando el padre de Rosana acude a la habitación de Alejandro con la intención de asesinarlo con una flecha envenenada; Tribalce, que se hallaba en la alcoba en ese mismo momento, se interpone entre la víctima y el verdugo, impulsado por un sentimiento de gratitud hacia el héroe griego, quien siempre le había dispensado un buen trato. Alejandro lamenta profundamente el infortunado deceso, y, en señal de agradecimiento, ordena dedicar a Tribalce magníficas exequias, así como construir un lujoso sepulcro donde reposen sus restos. 
Es entonces, como consecuencia de este suceso luctuoso, cuando Alejandro acepta casarse con Rosana:

pues por mi causa este día

perdisteis tan digno esposo, creo que a mí de justicia me toca recompensaros su pérdida... (p. 30).

Por tanto, como vemos, el matrimonio entre Alejandro y Rosana no resulta de la obcecación de un monarca esclavizado por la pasión amorosa; antes bien, lo que mueve a Alejandro es, más que todo el amor que siente por la joven, su deber real de actuar con raciocinio y justicia.

Respecto a la otra comedia aludida, El grande Alejandro en Asia, aquí es la amada de Alejandro, la reina Talestres, la que - al final de la obra- ofrece su mano motu proprio al monarca macedonio, quien la admite complacido. A simple vista, este proceder de Alejandro podría interpretarse como una claudicación del héroe ante sus pulsiones amorosas. Ahora bien, visto no como un hecho aislado sino en el conjunto global de la comedia, el concierto matrimonial entre Alejandro y Talestres se presenta como la solución más "racional" con la que podía cerrarse la obra, a tenor de los siguientes datos: por un lado, el amor que Laurante siente por Talestres, además de no ser correspondido por esta última, parece responder más a un capricho del rey de Hircania que a un sentimiento sincero y meditado, lo que legitimaría, a los ojos del espectador, la relación entre Talestres y Alejandro. Por otro lado, la intervención en la comedia del personaje de Delmira, hermana de Alejandro, cubriría el puesto que habría dejado vacante Talestres, pues Delmira profesa un inmenso amor a Laurante, y a éste tampoco parece desagradarle del todo ese afecto; tanto es así que, al acabar la comedia, Laurante tiene a bien prometerse con Delmira. De este modo, el dramaturgo articula un cuadrángulo amoroso, que, lejos de suponer un triunfo enardecido de las pasiones, se ajusta bastante - como hemos visto- al sentido común y al buen juicio.

Por último, conviene detenerse en otra de las cualidades más renombradas de Alejandro Magno y que, por lo demás, mejor contribuía a reforzar la imagen de solvencia económica e intelectual que querían transmitir los Borbones en la España del siglo XviII, frente a la ruina personificada en los Austrias; nos referimos a la virtud de la liberalidad. 
Nuestras comedias nos transmiten una idea de Alejandro como un monarca generoso, admirablemente desprendido con los miembros de su ejército (e, incluso, con los del bando enemigo); por ejemplo, en el acto II de Alejandro en Oxidraca, el monarca griego ordena a Peucestes, uno de sus capitanes, que sean repartidos mil talentos de oro entre sus hombres (f. $17 \mathrm{v}$ ). Este gesto se repite en numerosas ocasiones en Alejandro en la Sogdiana; al poco de comenzar la comedia, el héroe griego da la orden de que su tesorero Pérdicas entregue dos mil escudos a Filipo, el médico de Alejandro. Más conmovedora es la escena que se nos presenta a inicios del acto II, al ser un anciano el personaje implicado en la misma; a saber: Alejandro está hablando con Licagoras y Filipo cuando ve pasar a un soldado de edad avanzada, que transporta hasta ese lugar un talego por orden de un general macedonio; el anciano se queja de tener que llevar el saco sobre sus hombros debido a la resistencia de su vieja acémila a cargar con él; viendo el disgusto del soldado, Alejandro decide premiar sus servicios, por lo que le regala el talego, en cuyo interior se contiene parte de un rico botín. Instantes después de suceder esto, Pérdicas informa a Alejandro que el general Anajarque le ha pedido cien talentos, pero que él no ha querido entregarle tal cantidad de dinero por considerarla excesiva; la cicatería del tesorero es reprendida por el monarca macedonio de la siguiente manera:

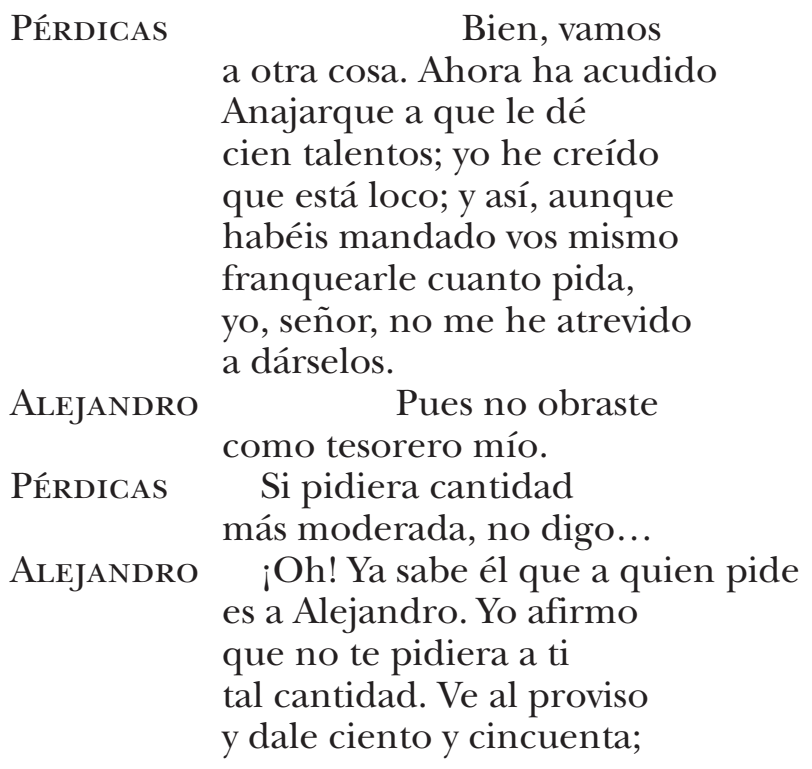


mas desde hoy queda advertido

que yo quiero un tesorero

pródigo como yo mismo.

Pérdicas Si así dais, no os bastarán

los tesoros excesivos

de Europa.

Alejandro

y África.

Ahí están los de Asia

Pérdicas Bien, no replico;

daréle cuanto me pida

de mala gana, os lo afirmo. Vase.

Alejandro Pérdicas está empeñado

en querer hacerme rico,

sin ver que nadie lo es más

que el que más da a sus amigos (pp. 11-12).

Pero las muestras de generosidad de Alejandro en esta comedia no se reducen a esto, ya que, avanzado el acto II, resuelve repartir entre todo su ejército el botín obtenido en la conquista del castillo de Sogdiana. En tal reparto, Alejandro hace ostensible su gran magnanimidad, al destinar una parte del botín al auxilio de los soldados desvalidos, sin reservar nada para él:

Representa

Los quinientos,

Pérdicas, haz que al proviso

se repartan entre aquellos

soldados que, o por heridos

o enfermos, ninguna parte

en el botín han tenido,

y los que hereden a aquellos

que, al asaltar el castillo,

hayan muerto; otros quinientos

entre tantos peregrinos

artistas, como dejaron

sólo por venir conmigo

sus casas y conveniencias,

y hoy se hallan en mi servicio (p. 15).

A lo largo de estas páginas se ha comprobado lo que ya anunciábamos al comienzo de nuestro trabajo, esto es, que las comedias estudiadas conforman un perfil sumamente idealizado de Alejandro Magno. Es posible afirmar que dicho perfil queda realzado 
en estas obras por contraste con la caracterización negativa de otro personaje dramático (normalmente, algún miembro destacado del ejército contrario a los macedonios), el cual suele ser cobarde, cruel, egoísta e incapaz de moderar sus pasiones. Prueba de ello es la propensión al suicidio que muestran casi todos estos personajes; tal es el caso de Sogramnes (Alejandro en Oxidraca), que, al verse derrotado por los griegos y a su querida Demofonia en poder de Alejandro, no reacciona intentando hacer frente a esa adversidad; antes bien, se entrega al desánimo e intenta herirse con una flecha; huelga decir que, con este comportamiento, Sogramnes estaría anteponiendo sus deseos al bien de la patria - lo contrario que hacía Alejandro-, como le recrimina su confidente Teutiles en el siguiente fragmento:

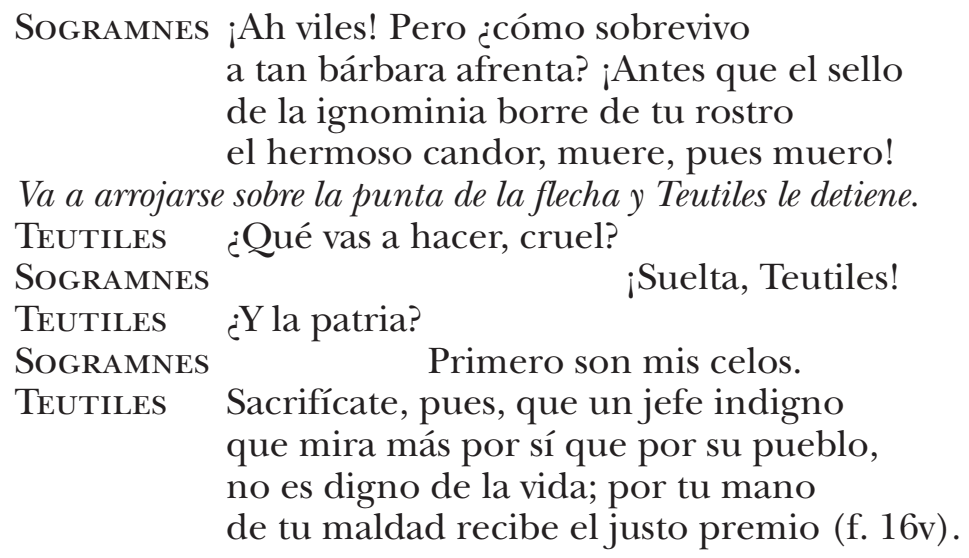

Exactamente lo mismo observamos en El generoso vencedor de Oriente con el personaje del rey Poro, que intenta quitarse la vida hasta en dos ocasiones a lo largo de la comedia. La primera tentativa de suicidio se produce nada más comenzar la obra, cuando las tropas macedonias acaban de vencer a los indios dirigidos por Poro. La otra tentativa tiene lugar en el acto III y viene motivada por una nueva victoria de los soldados de Alejandro sobre los de Poro. En ambos casos, los planes suicidas de este último se ven frustrados gracias a la intervención del general Gandarte, confidente del rey indio - al igual que sucedía con Teutiles, confidente de Sogramnes, en Alejandro en Oxidraca, según vimos más arriba. Otra coincidencia que se observa entre esta última comedia y la que ahora examinamos es que el rey Poro — del mismo modo que Sogramnes y en contraposición a Alejandro- se nos revela como un gobernante dominado por las 
pasiones; esto se aprecia muy bien a inicios del acto II, momento en que los indios se disponen a ejecutar una emboscada contra Alejandro en la ribera del río Hidaspes, donde el héroe griego va a desembarcar para verse con Cleofida; ésta lo ha citado en su palacio con el objeto de intentar mediar a favor de Poro. Cuando Erisena llega ante su hermano Poro para avisarle de la inminente venida de Alejandro, el rey indio rehúsa acudir rápidamente a la emboscada; en unos instantes tan cruciales para su ejército, Poro no piensa más que en aplacar los celos que ha suscitado en él la noticia de que Cleofida haya salido de su palacio para recibir a Alejandro, de lo que le ha informado Erisena:

$\begin{array}{ll}\text { Poro } & \begin{array}{l}\text { ¡Ingrata! Amigo tierno } \\ \text { ve, corre, vuela, aguárdame en el sitio. }\end{array} \\ \text { GANDARTE } & \begin{array}{l}\text { Mas, ¿tú no vienes? } \\ \text { Poro }\end{array} \\ & \begin{array}{l}\text { Sí, pero primero } \\ \text { de la traidora quiero ante los ojos } \\ \text { la imagen presentar de mis tormentos. } \\ \text { iQuiero decirla que es infiel, perjura, } \\ \text { execrable mujer!; y entonces, quedo } \\ \text { de mi derrota y mi dolor profundo } \\ \text { compensado y alegre y satisfecho. }\end{array} \\ \text { GANDARTE } & \text { ¿Y tú piensas ahora en su inconstancia? } \\ & \begin{array}{l}\text { Del almo honor los resonantes ecos } \\ \text { te están llamando de la gloria al triunfo }\end{array} \\ & \text { en más feliz y delicado empeño. } \\ \text { Poro } & \text { Ve tú, Gandarte amado, que muy breve } \\ \text { seguiré yo tu planta. } & \text { ¡Oh, amor funesto, } \\ \text { GANDARTE } & \text { funesto siempre al universo todo } \\ & \text { y a los héroes también aún más funesto! } \\ & \end{array}$

De las obras dramáticas aquí estudiadas, la única en la que no parece darse de manera tan obvia este contraste entre la caracterización (positiva) de Alejandro y la (negativa) de otro personaje es la comedia titulada Alejandro en Scutaro. En ella encontramos a Protulo, el gobernante de Scutaro, cuya personalidad no resulta de ningún modo negativa; por el contrario, éste es caracterizado como un líder carismático, valiente, modesto y racional; tanto es así que, con sus acciones, llega a ensombrecer bastante la figura de su enemigo Alejandro; este último adopta en la comedia un perfil muy bajo, irreconocible incluso en 
algunos de sus rasgos más idiosincrásicos, cediendo protagonismo al citado líder de Scutaro. Es más, aunque no se aprecia una caracterización por contraste entre Alejandro y Protulo, ésta sí se daría entre Protulo y su lugarteniente Fenice, hombre soberbio, ambicioso y sin escrúpulos. Así pues, el personaje de Protulo parece asumir en esta obra el mismo papel funcional que desempeñaba Alejandro en las otras comedias consideradas.

No obstante, hay que decir que ese perfil bajo adoptado por el monarca macedonio se mantiene durante los dos primeros actos de la comedia, pero desaparece $-\mathrm{o}$, al menos, se atenúa- en el tercer acto. Es en esta última parte de la obra cuando se vuelven a concentrar todas las miradas en Alejandro, a quien - ahora sí-identificamos con sus heroicas cualidades de siempre. Este recobrado protagonismo por parte de nuestro héroe se observa especialmente bien en la escena final de la comedia: Scutaro ha caído en manos macedonias y a Alejandro se le presenta la oportunidad de matar a Protulo; en cambio, el rey griego desaprovecha esa oportunidad y, haciendo uso de su conocida clemencia, no sólo acaba perdonando la vida de Protulo sino que, además, le restituye el gobierno de Scutaro y a su esposa Timoclea, de la que Alejandro está enamorado:

\author{
Ea, Alejandro, no ceda \\ tu heroicidad. Nobles griegos, \\ vuestro esclarecido César \\ va a hacer la acción más notable \\ con su enemigo. La ofensa \\ es enorme; su delito \\ está pidiendo la pena \\ más grande; sí, pero excede \\ a mi furor la clemencia; \\ aquel amor, aquel fuego \\ tan activo, ya en pavesas \\ se ha reducido. Disfruta \\ de tu amada Timoclea \\ sin recelo; yo te cedo \\ la singular preeminencia \\ gustoso, pues no es posible \\ se concilien dos estrellas \\ tan contrarias; de esta plaza \\ te concedo la suprema \\ autoridad del gobierno \\ absoluto, sin que pueda \\ nadie envidiar tu fortuna.
}



Mira cuánta diferencia
hay entre tan gran delito
y el premio que te dispensa
mi gratitud; de mí propio
quiero triunfar, por que vea
el orbe cómo Alejandro
vuelve en premios las ofensas (p. 32) ${ }^{24}$.

A tenor de lo que llevamos dicho, cabría preguntarse por qué el dramaturgo dedica tanto espacio y atención en los primeros actos de esta comedia a ensalzar a Protulo, dejando un poco de lado a Alejandro Magno. A nuestro juicio, lo que se pretende con ello es transmitir al espectador la idea de que, durante su trayectoria vital, el hijo de Filipo II de Macedonia tuvo que batirse con adversarios menos carismáticos que él, pero también con otros tantos que estaban muy bien dotados política y militarmente (como era el caso de Protulo). De este modo, con su proceder, el dramaturgo no buscaría más que subrayar la heroicidad de Alejandro.

\section{Algunas Pinceladas SObRe ESCENOGRafía}

No queremos cerrar este trabajo sin antes dedicar unas breves líneas a la puesta en escena de nuestros textos dramáticos, puesto que, aunque no sea el objeto de nuestro estudio, el despliegue escenográfico constituía una de las características más sobresalientes de la comedia heroico-militar, fórmula dramática a la que se adscriben nuestras obras, como ya se dijo antes.

Sabido es que, en la época en que nos movemos, el montaje escenográfico ayudaba no poco al éxito o fracaso de una representación dramática. Como subraya Andioc - entre otros estudiosos- en su libro Teatro y sociedad en el Madrid del siglo XVIII (1987), el pueblo español dieciochesco demandaba espectacularidad en las tablas, una demanda que ya provenía del Barroco pero que no será hasta el Setecientos cuando se vea plenamente colmada, gracias a la incorporación definitiva a los teatros públicos de medios técnicos que hacían posibles rápidos e impresionantes cambios de escena, llenos de fastuosidad. De este modo, España se alineaba con la tendencia existente a este respecto

${ }^{24}$ Citamos esta obra según el ejemplar impreso T/11645 de la Biblioteca Nacional de España. 
en la Europa dieciochesca, en la que se inventaron numerosas máquinas que permitían "la reproducción visual de detalles escénicos, dentro y fuera de edificios - a escaleras, galerías, fuentes, tempestades, luz, oscuridad, etc., y detalles de actividades complicadas como batallas, etc." (McClelland 1996, p. 629).

Las comedias heroico-militares, por su argumento de raíz bélica, se prestaban muy bien al fulgor tramoyístico, lo que convirtió esta fórmula dramática en una de las más poderosas del siglo, junto a otras como las comedias de santos y las comedias de magia, que conforman el llamado "teatro espectacular" (Palacios Fernández 1996, p. 142).

Como explica Guillermo Carnero (1989), eran múltiples los recursos utilizados por los escritores de comedias heroico-militares para engrandecer la representación de sus obras; los cinco textos que hemos estudiado en este artículo dan buena muestra de ello, según veremos en seguida.

Al situar su acción en un ámbito geográfico alejado como Oriente, nuestras comedias sobre Alejandro Magno rezuman un cierto aire exótico, que, sin lugar a dudas, fascinaría al espectador español setecentista. La comedia Alejandro en Oxidraca, por ejemplo, nos adentra en este exotismo desde el primer momento, a través de su acotación inicial: "Vista de una arboleda de plátanos con río en el foro. Salen Sogramnes, Theutiles e indios con flecha y clavas" (f. 18r); el carácter exótico reaparece más adelante en esta misma comedia, en uno de los decorados a los que se recurre en el acto II: "Jardín con palmas y otros árboles en el foro, el cual termina un lienzo de muralla en la cual habrá un postigo que figura dar al campo. En un asiento que habrá junto a una fuente estará Demofonia dormida, en parte cubierta con un pequeño plátano..." (f. 13r). Volvemos a encontrar las palmas, junto a otros árboles como el ciprés, en El generoso vencedor de Oriente: "Recinto de palmas y cipreses con un pequeño templo en medio dedicado a Baco en el palacio de Cleofida..." (f. 13r). Igualmente exótico resulta el empleo de animales como camellos —en Alejandro en Scutaro: "Salen varios camellos conducidos de algunos soldados y, detrás, Fenice, llevando aquéllos cargas de bastimentos y armas" (p. 6) - o elefantes —en El generoso vencedor de Oriente: “... Campo numeroso de Alejandro dispuesto en orden a la otra parte del río con elefantes, torres, carros cubiertos y máquinas de guerra" (f. 5r).

Puesto que se trata de comedias heroico-militares, abundan en nuestras obras decorados como campamentos, salones regios, cadalsos, fortificaciones, etc. (véase Carnero Arbat 
1989). Tenemos un ejemplo en El grande Alejandro en Asia, cuyo acto I comienza "en una tienda de campaña" (f. 10r) donde hallamos, entre otros, al monarca macedonio en presencia de Hefestión y otros soldados. Ahora bien, es la comedia Alejandro en Scutaro la que nos ofrece el repertorio más diverso de estos decorados, según los tipos que acabamos de citar más arriba; lo vemos en la siguiente selección:

Salones: "Salón regio con vistosas columnas y magníficos arcos, escalera al frente y un elevado trono en la superficie de ella; dosel grande y, bajo de él, la estatua o busto de Dario; sillas a derecha e izquierda junto a él; tocan una gran marcha y sale la comparsa de soldados, ocupando el centro y costados del teatro..." (p. 14).

Tiendas de campaña: "Selva larga con varias tiendas de campaña. Salen Alejandro, Filotas, Ificrates y Arsinoe, precedidos de la comparsa de macedonios y tocan caja y clarín haciendo salva" (p. 7); "Selva corta con tiendas de campaña a ambos lados..." (p. 16); "Tienda de campaña, que ocupe toda la escena..." (p. 23).

Cárceles: "Cárcel obscura, lamparilla a la izquierda, y a la derecha Fenice sentado con cadena" (p. 13).

Cadalsos: "Plaza ovalada magnifica, ocupadas sus ventanas y balcones de diversos personajes. En medio de ella un gran tablado enlutado con escaleras a derecha e izquierda" (p. 20).

Fortificaciones: "Selva corta. A la izquierda fachada de la ciudad o puerta transitable en cubo de muralla..." (p. 22); "Perspectivas de la ciudad de todo foro, cubos de muralla a ambos lados, que ocupe todo el teatro... La muralla coronada de tropas y Ceroneo" (pp. 30-31).

Estos decorados acogen toda clase de acciones hostiles entre Alejandro y sus enemigos, acciones que pueden ir desde incendios - como el provocado por Oxiarte en el campamento de los macedonios en Alejandro en la Sogdiana: "Acampamento de Alejandro incendiado. Descúbrense algunos soldados con picos y hachas, destruyendo las tiendas y otros apagando el incendio con cubos de agua, que conducirán a este efecto después de las primeras voces..." (p. 29) - hasta cruentas batallas — como la que tiene lugar entre Alejandro y los hombres de Protulo en Alejandro en Scutaro: "Dase la batalla con ardor, subiendo por las escalas los macedonios, resistiendo los sitiados..." (p. 9). Con vistas a comprobar el grado de precisión al que llegan las acotaciones de algunas comedias heroico-militares de la época en la descripción de este tipo de escenas bélicas, traemos a colación el siguiente ejemplo extraído de Catalina Segunda, emperatriz de Rusia, de Comella: 
Acampamento con vista de la figurada plaza de Oczakow, cuyos muros estarán destruidos con brechas abiertas. Aparecen las tropas prontas para dar el asalto. Entre los granaderos estará Nicolas Zastrow y Weymar. Catalina se deja ver en una hermosa tienda o palco, acompañada de Sofia, Alejandro, damas y demás acompañamiento. Potemkin toma la venia de su soberana para que empiecen a maniobrar sus tropas; a su señal salen una partida de sargentos precedida de tambores, que tocan Bando figurando van a publicar el que precedió a la toma; a otra señal del general tocan a ataque, y se empieza el asalto entre rusos y turcos, demostrando el tesón de unos y otros. Después de varios encuentros en las empalizadas, trepa Nicolás Zastrow por ellas y se le ve la acción del muro y la herida que recibió. Apoderados los rusos de los muros, pelean con los turcos dentro de la plaza donde Nicolás quita el grande estandarte al Baxá, el que ofrece a los pies del general. Perdido el estandarte huyen los turcos y los siguen los rusos. Una partida de griegos viene peleando con Nicolás y otros. Después de varios encuentros quedan solos Nicolas Zastrow, Andrés Neker y un herido, y sucede el reconocimiento del modo que está pintado en el primer acto. Salva a su padre, se coloca el estandarte ruso en el muro, se vuelan los almacenes de pólvora, y de entre las ruinas saca el teniente al conde de Damas. Tocan retirada y desfilan las tropas delante de la emperatriz, que dará las mayores muestras de complacencia. Acabado sale Catalina con toda su comitiva, quedándose a la vista algunas tropas; todo esto debe ser con los toques de ordenanza y acompañado de música militar $\left(1795\right.$, pp. 32-33) ${ }^{25}$.

Como vemos, no es infrecuente que estas acciones cuenten con un apoyo musical; así ocurre con la batalla que protagonizan los macedonios y los indios al poco de iniciarse la comedia Alejandro en Oxidraca, batalla que, según indica la acotación, "será acompañada de la música" (f. 16r); en el acto II de esta obra se produce un nuevo enfrentamiento entre ambos bandos, en el que también contamos con la participación musical:

Alejandro baja con la mayor precipitación del muro por el árbol; acomete a los indios que tienen a Demofonia, la que huye. Los indios pelean con Alejandro, los que se van aumentando sucesivamente; interin se oye un ruido de arietes y máquinas que intentan derribar el muro. Los indios desde las torres disparan siempre flechas. Después de haber peleado contra todos los indios y éstos habiéndole cobrado miedo, se ponen divididos en dos filas a alguna distancia. Alejandro se arrima al árbol para defenderse mejor y descansar de la fatiga. Todo esto habrá sido expresado por la música (f. 4v).

${ }^{25}$ Citamos esta obra según el ejemplar impreso PQ6225.T43 v.18 de la University of North Carolina at Chapel Hill. 
Pero la intervención de la música no se reduce únicamente a las batallas, sino que puede emplearse en cualquier otro momento destacado de la acción dramática (Carnero Arbat 1989, p. 31); por ejemplo, en el acto I de El generoso vencedor de Oriente, el desembarco de la reina Cleofida y de su ejército ante Alejandro tiene lugar al son de "una breve sinfonía" (f. $19 \mathrm{v}$ ); igualmente, en El grande Alejandro en Asia, se recurre a la música para subrayar la llegada de la reina Talestres y de su séquito al campamento del monarca macedonio (f. 13v). Asimismo, la música puede funcionar como "correlato de las emociones de personajes y espectadores, o del clima emocional de determinadas situaciones" (Carnero Arbat 1989, p. 29); esto es lo que ocurre en Alejandro en Oxidraca, cuando, en el acto II, Demofonia va a ser ajusticiada. La acotación nos informa que los indios sacan a la mujer "al son de una marcha lúgubre con el pelo suelto y una guirnalda de ciprés" (f. 5r). El ajusticiamiento de Fenice en Alejandro en Scutaro también se advierte mediante una "lúgubre marcha de sordinas y cajas" (p. 20).

\section{Conclusiones}

Cualquier régimen político, antes y ahora, se ha valido en mayor o menor medida de la propaganda para reforzar y perpetuar su poder en el tiempo; como afirman Pablo Valdés Phillips y Juan Salazar Sparks (1987),

Desde la época de la Edad Media, los Estados han tenido presente la necesidad de publicitar su política, interna y externamente, así como de evitar que, a la inversa, las campañas hostiles provenientes del exterior o del mismo país puedan dañar dicha política. Esta necesidad de los Gobiernos revela la importancia de, por una parte, poder controlar a una opinión pública y, por la otra, de impedir verse controlado por ella... Es por ello que la propaganda es, en última instancia, un instrumento de acción sicológica que dispone un Estado para influir, o lisa y llanamente controlar, la opinión pública nacional y extranjera frente a un determinado tópico. Constituye, en otras palabras, el "ropaje" con que se viste una política de Gobierno (p. 51).

La España del siglo xviıI constituye un buen ejemplo de ello. La acción nefasta de los últimos Habsburgo había dejado un país desolado política y económicamente, con el consiguien- 
te deterioro del prestigio de la Corona. Ante este panorama, la nueva Casa Real entrante, la Borbónica, debía proceder con agilidad y rapidez si quería atajar de raíz la crisis institucional en la que se hallaba la Península. Una de las vías para conseguirlo consistía en lanzar a la opinión pública una imagen nueva, renovada, límpida, de la monarquía como institución capaz de garantizar la prosperidad de los súbditos. Esto pasaba, claro está, por difundir una visión nueva del monarca, más cercana $(\mathrm{y}$, al mismo tiempo, fastuosa), que contrastara con la lejanía y la sobriedad que habían caracterizado a la dinastía anterior. A este fin propagandístico podía contribuir perfectamente la Antigüedad grecorromana, dado el elenco de arquetipos regios que lograba poner en circulación. Uno de estos arquetipos era, sin lugar a dudas, Alejandro Magno, que, por su vigor y fuerte raigambre en el imaginario colectivo, pasó a convertirse en una poderosa herramienta de propaganda ideológica en manos de los Borbones. Muestra de ello son las cinco comedias heroico-militares en las que aquí nos hemos centrado. El análisis de estas obras pone de manifiesto cómo la figura del héroe griego fue utilizada, desde las tablas, para transmitir un conjunto de imágenes políticas que estaban muy en consonancia con las que la monarquía borbónica buscaba proyectar de sí misma a través de otro tipo de medios y soportes artísticos — tal es el caso de los retratos pictóricos, la creación de academias, las colecciones de arte o los descubrimientos arqueológicos, con los que se pretendía trazar puentes entre la realidad española de la época y el pasado grecolatino antes aludido. En este sentido, no es de extrañar que una de estas comedias (concretamente, la titulada Alejandro en Scutaro) se pusiese en escena en 1792 con motivo de un evento real de gran relevancia, la celebración del cumpleaños de Carlos IV (Herrera Navarro 1993, p. 70).

En resumidas cuentas, con nuestro artículo se confirma una vez más que, en la España del siglo XviII, el arte de Talía penetró fuertemente en el terreno de la acción política.

\section{REFERENCIAS}

\section{Corpus}

Alejandro o el generoso vencedor de Oriente 1800. En Biblioteca Histórica Municipal de Madrid (Ms. Tea 1-33-17, A), http:/ / www.memoriademadrid.es/ 
buscador.php?accion=VerFicha\&id=342148\&num_id=1\&num_total=1 [consultado el 14 de julio de 2019].

Calvo de Barrionuevo, José 1792. Razón, justicia y honor triunfan del mayor valor. Alejandro en Scutaro, en Biblioteca Nacional de España (T/11645), http:/ /bdh-rd.bne.es/viewer.vm?id=0000133296\&page $=1$ [consultado el 22 de julio de 2019].

Comella, Luciano Francisco 1794. Alejandro en Oxidraca, en Biblioteca Histórica Municipal de Madrid (Ms. Tea 1-1-14, B), http://www.memoriademadrid.es/buscador.php?accion=VerFicha\&id=342135 [consultado el 10 de julio de 2019].

Díaz Domínguez Robles, Francisco 1764. Hay pena mayor que celos sin llegar a ser agravios y el grande Alejandro en Asia, en Biblioteca Nacional de España (ms. 15472), http://bdh-rd.bne.es/viewer.vm?id=0000215483\&page $=1$ [consultado el 15 de julio de 2019].

Zavala y Zamora, Gaspar 1795. Alejandro en la Sogdiana, en Biblioteca Histórica Municipal de Madrid (Tea 1-84-1, a), http://www.memoriademadrid.es/buscador.php?accion=VerFicha\&id=341928 [consultado el 21 de julio de 2019].

\section{Referencias bibliográficas}

Aguilar Piñal, Francisco 1981-2002. Bibliografía de autores españoles del siglo XVIII, Consejo Superior de Investigaciones Científicas, Madrid.

Álvarez Lopera, José 2002. "Las virtudes del Rey. Las historias de Alejandro Magno para el palacio de La Granja”, en El arte en la corte de Felipe V. Coord. José Miguel Morán Turina, Fundación Caja de Madrid-Patrimonio Nacional-Museo Nacional del Prado, Madrid, pp. 141-156.

Andioc, René 1987. Teatro y sociedad en el Madrid del siglo XVIII, Castalia, Madrid.

Andioc, René y Mireille Coulon 1997. Cartelera teatral madrileña del siglo XVIII (1708-1808), Presses Universitaires du Mirail, Toulouse.

Anes Álvarez, Gonzalo 1981. Economía e Ilustración en la España del siglo XVIII, Editorial Ariel, Barcelona.

Bonet Correa, Antonio 1994. "Un emblema inédito de José de Churriguera”, Ars longa. Cuadernos de arte, 5, pp. 31-33.

Carneiro, SArissa 2013. "La clemencia del príncipe: su representación alegórica en emblemas y empresas de España y América colonial", Revista Chilena de Literatura, 85, pp. 75-100; doi: 10.4067/S071822952013000300004.

Carnero Arbat, Guillermo 1989. "Recursos y efectos escénicos en el teatro de Gaspar Zavala y Zamora”, Bulletin Hispanique, 1, pp. 21-36; doi: 10.3406/hispa.1989.4661.

Cejador y Frauca, Julio 1917. Historia de la lengua y literatura castellana, t. 6, Tipografía de la Revista de Archivos, Bibliotecas y Museos, Madrid. 
Comella, Luciano Francisco 1795. Catalina Segunda, emperatriz de Rusia, en University of North Carolina at Chapel Hill (PQ6225.T43 v.18).

$D L E=$ Real Academia Española, Diccionario de la lengua española, $23^{\mathrm{a}}$ ed., [versión 23.4 en línea], https://dle.rae.es/?id=ZQm69KL [consultado el 10 de septiembre de 2019].

Domínguez Ortiz, Antonio 1981. Sociedad y Estado en el siglo xVIII español, Editorial Ariel, Barcelona.

Fernández Cabezón, Rosalía 1987. "Los sainetes de Gaspar Zavala y Zamora”, Castilla. Estudios de Literatura, 12, pp. 59-72; hdl: 10324/15362.

Fernández Cabezón, Rosalía 1989. "Las loas de Gaspar Zavala y Zamora”, Boletín de la Biblioteca de Menéndez Pelayo, 65, pp. 191-203.

Fernández Díaz, Roberto 2012. "Absolutismo borbónico y teatro en la España del Setecientos”, en El teatro en la España del siglo XVIII. Homenaje a Josep Maria Sala Valldaura. Coords. Judith Farré Vidal, Nathalie Bittoun-Debruyne y Roberto Fernández, Universitat de Lleida, Lleida, pp. 45-58.

Gómez Espelosín, Francisco Javier 2016. En busca de Alejandro: historia de una obsesión, Universidad de Alcalá, Alcalá de Henares.

Herrera Navarro, Jerónimo 1993. Catálogo de autores teatrales del siglo xVIII, Fundación Universitaria Española, Madrid.

Lafarga Maduell, Francisco 1986-87. “Traducción e historia del teatro: el siglo Xviı español”, Anales de Literatura Española, 5, pp. 219-230; doi: 10.14198/ALEUA.1986-1987.5.12.

Leal Bonmati, María del Rosario 2008. "Las Besugueras, de Gaspar Zavala y Zamora”, en Teatro y música en España: los géneros breves en la segunda mitad del siglo XVIII. Coords. Joaquín Álvarez Barrientos y Begoña Lolo, Universidad Autónoma de Madrid, Madrid, pp. 393-406.

Maier Allende, Jorge 2010. "Las antigüedades en Palacio: ideología y función de las Colecciones Reales de arte antiguo en el siglo xviII", Reales Sitios. Revista del Patrimonio Nacional, 183, pp. 6-29.

Maravall, José Antonio 1982. "La función educadora del teatro en el siglo de la Ilustración”, en Estudios dedicados a Juan Peset Aleixandre, Universidad de Valencia, Valencia, t. 2, pp. 617-642.

Martín Puente, Cristina 2013. "Las obras sobre la historia de Roma de Metastasio y sus traductores al español con especial atención al jesuita Benito Antonio de Céspedes”, Cuadernos de Investigación Filológica, 39, pp. 187-204; doi: 10.18172/cif.2561.

Martín Sarmiento, fray 2002. Sistema de adornos del Palacio Real de Madrid. Eds. Joaquín Álvarez Barrientos y Concha Herrero Carretero, Sociedad Estatal de Conmemoraciones Culturales, Madrid.

McClelland, Ivy L. 1996. "En los alrededores del «Ilustrismo»: Cándido María Trigueros y Antonio Valladares”, en El siglo que llaman ilustrado. 
Homenaje a Francisco Aguilar Piña. Coords. Joaquín Álvarez Barrientos y José Checa Beltrán, Consejo Superior de Investigaciones Científicas, Madrid, pp. 629-634.

Morán Turina, José Miguel 1988. "Felipe V y la guerra: la iconografía del primer Borbón”, Cuadernos de Arte e Iconografía, 1, 1, pp. 187-200.

Palacios Fernández, Emilio 1996. "Teatro", en Historia literaria de España en el siglo XVIII. Ed. Francisco Aguilar Piñal, Trotta, Madrid, pp. 135-233.

Peña Lázaro, María del Rosario 1990. El infante don Luis de Borbón, coleccionista y mecenas, Universidad Autónoma de Madrid, Madrid.

Pérez SAmper, María de los Ángeles 2011. "La imagen de la monarquía española en el siglo xviı", Obradoiro de Historia Moderna, 20, pp. 105139; doi: 10.15304/ohm.20.9.

Romanos, Melchora 2000. "Alejandro Magno y la ejemplaridad de la historia antigua en el teatro de Calderón”, en Calderón 2000. Homenaje a Kurt Reichenberger en su 80 cumpleaños. Actas del Congreso Internacional "IV Centenario del Nacimiento de Calderón”. Dir. Ignacio Arellano Ayuso, Reichenberger, Kassel, t. 1, pp. 789-802.

Soler Villalobos, María Paz 2004. "El Palacio Real de La Granja. De retiro espiritual a escenario cortesano", en El entorno de Segovia en la historia de la dinastía de Borbón. Coord. María Paz Soler Villalobos, Ministerio de Educación, Cultura y Deporte, Madrid, pp. 17-34.

Valdés Phillips, Pablo y Juan Salazar Sparks 1987. Manual de política mundial contemporánea, Editorial Andrés Bello, Santiago de Chile. 